\title{
The Catestatin-Derived Peptides Are New Actors to Fight the Development of Oral Candidosis
}

\author{
Davide Mancino ${ }^{1,2,3,+} \oplus^{\oplus}$, Naji Kharouf ${ }^{1,2, *,+}{ }^{+}$, Francesco Scavello ${ }^{1,+}$, Sophie Hellé ${ }^{1}$, Fouad Salloum-Yared ${ }^{4}$, \\ Angela Mutschler ${ }^{1}$, Eric Mathieu ${ }^{1}$, Philippe Lavalle ${ }^{1}$, Marie-Hélène Metz-Boutigue ${ }^{1}$ and Youssef Haïkel ${ }^{1,2,3}$ \\ 1 Department of Biomaterials and Bioengineering, INSERM UMR_S 1121, University of Strasbourg, \\ 67000 Strasbourg, France; mancino@unistra.fr (D.M.); francescoscav@tiscali.it (F.S.); s.helle@unistra.fr (S.H.); \\ angela.mutschler@u-bordeaux.fr (A.M.); eric.mathieu@inserm.fr (E.M.); philippe.lavalle@inserm.fr (P.L.); \\ marie-helene.metz@inserm.fr (M.-H.M.-B.); youssef.haikel@unistra.fr (Y.H.) \\ 2 Department of Endodontics and Conservative Dentistry, Faculty of Dental Medicine, University of Strasbourg, \\ 67000 Strasbourg, France \\ 3 Pôle de Médecine et Chirurgie Bucco-Dentaire, Hôpital Civil, Hôpitaux Universitaire de Strasbourg, \\ University of Strasbourg, 67000 Strasbourg, France \\ 4 Department of Medical Laboratory, The General Authority of the Syrian Arab Red Crescent Hospital, \\ Damascus 0100, Syria; fouad.yar@gmail.com \\ * Correspondence: dentistenajikharouf@gmail.com; Tel.: +33-66752-2841 \\ + These authors contributed equally to this work.
}

check for updates

Citation: Mancino, D.; Kharouf, N.; Scavello, F.; Hellé, S.; Salloum-Yared, F.; Mutschler, A.; Mathieu, E.; Lavalle, P.; Metz-Boutigue, M.-H.; Haikel, Y. The Catestatin-Derived Peptides Are New Actors to Fight the Development of Oral Candidosis. Int. J. Mol. Sci. 2022, 23, 2066. https:// doi.org/10.3390/ijms23042066

Academic Editor: Satish Raina

Received: 13 January 2022

Accepted: 11 February 2022

Published: 13 February 2022

Publisher's Note: MDPI stays neutral with regard to jurisdictional claims in published maps and institutional affiliations.

Copyright: (C) 2022 by the authors. Licensee MDPI, Basel, Switzerland. This article is an open access article distributed under the terms and conditions of the Creative Commons Attribution (CC BY) license (https:// creativecommons.org/licenses/by/ $4.0 /)$.

\begin{abstract}
Resistance to antifungal therapy of Candida albicans and non-albicans Candida strains, frequently associated with oral candidosis, is on the rise. In this context, host-defense peptides have emerged as new promising candidates to overcome antifungal resistance. Thus, the aim of this study was to assess the effectiveness against Candida species of different Catestatin-derived peptides, as well as the combined effect with serum albumin. Among Catestatin-derived peptides, the most active against sensitive and resistant strains of $C$. albicans, C. tropicalis and C. glabrata was the $D$-isomer of Cateslytin $(D$-bCtl) whereas the efficiency of the $L$-isomer $(L-b C t l)$ significantly decreases against $C$. glabrata strains. Images obtained by transmission electron microscopy clearly demonstrated fungal membrane lysis and the leakage of the intracellular material induced by the $L-b C t l$ and $D-b C t l$ peptides. The possible synergistic effect of albumin on Catestatin-derived peptides activity was investigated too. Our finding showed that bovine serum albumin (BSA) when combined with the $L$ - isomer of Catestatin ( $L$-bCts) had a synergistic effect against Candida albicans especially at low concentrations of BSA; however, no synergistic effect was detected when BSA interacted with $L-b C t 1$, suggesting the importance of the C-terminal end of $L$-bCts (GPGLQL) for the interaction with BSA. In this context in vitro $D$-bCtl, as well as the combination of BSA with $L$-bCts are potential candidates for the development of new antifungal drugs for the treatment of oral candidosis due to Candida and non-Candida albicans, without detrimental side effects.
\end{abstract}

Keywords: candidosis; resistance; antifungal; antimicrobial peptides; Catestatin

\section{Introduction}

Candida species are part of the commensal flora of the mucous membranes and are opportunistic pathogens. Under appropriate conditions, they can be responsible for oral candidosis, the most common oral yeast mycoses encountered in humans [1]. Candida albicans is the most frequently isolated species associated with oral candidosis, accounting for between $60 \%$ and $75 \%$ [2,3] of cases and involving between $41 \%$ and $30 \%$ of candidemia episodes. However, over the last few years, non-albicans Candida strains, responsible for oral candidosis, have tended to increase, and together they cause the majority of Candida bloodstream infections, even though with important differences across countries and continents [4-7]. Recent epidemiological studies have reported an increased incidence of 
non-albicans candidemia, especially in the USA, Northern Europe, and Australia, due to Candida glabrata and Candida tropicalis, which are less susceptible to antifungal drugs and could be associated with high morbidity and high mortality [8-10]. These epidemiological data pose a growing threat to public health worldwide and the Interagency Coordination Group on antimicrobial resistance (IACG) has already expressed concerns about the increase in resistant pathogens, which could lead to overall treatment inefficiency [11]. In this context, there is a pressing demand for new active anti-Candida drugs.

Host-defense peptides (HDPs) have emerged as new attractive candidates in the development of new antimicrobial agents [12]. In addition, HDPs have been proven to be potent immune effectors via the orchestration of immune responses [13]. Furthermore, it has been amply demonstrated that the pro-hormone chromogranin $\mathrm{A}(\mathrm{Cg} \mathrm{A})$ is the precursor of several physiological HDPs [14-17] released under stress in most body fluids and saliva [18]. One of these HDPs, Catestatin (bCts, bovine CgA 344-364), initially described as a potent inhibitor of catecholamines release [19], displays direct antimicrobial activities [17], contributes to immune regulation, and may modulate severe inflammatory response [20-23]. It has been established that Cateslytin (bCtl, bovine CgA344358) is the active core of bCts [17] and that it resists bacterial degradation [24]. bCts and bCtl show a broad spectrum of antimicrobial activities against bacteria and yeasts when attached to biomaterials $[25,26]$. Additionally, we have previously characterized the antimicrobial and mechanistic properties of the $D$-isomer of bCtl where all $L$-amino acids have been replaced by $D$-amino acids [27-29].

A crucial role could be played by albumin, an indispensable molecule in the transport, distribution, and metabolism of many endogenous and exogenous ligands including small peptides and numerous pharmaceutical products. A recent study even reported that albumin could modulate C. albicans pathogenicity [30], whereas further work showed that continuous infusion of $4 \%$ albumin was effective in reducing care-related infections in shock patients by increasing the availability of HDP Vasostatin-I [31].

The aims of the present study are multifaceted: firstly, to carry out a drug-design study to characterize the most potent antimicrobial peptide derived from bovine and human Cts (bCts and hCts) able to inhibit the growth of different Candida strains, secondly to examine $L$ - and $D$-bCtl-Candida interaction, thirdly to investigate the activity against $C$. albicans of $L-b C t s / L-b C t l$ combined with albumin and finally to characterize the interaction of these peptides with albumin by using biophysical techniques.

\section{Results}

\subsection{Characterization of the Most Active Peptide against Candida albicans}

Different sensitive " $\mathrm{S}$ " and resistant " $\mathrm{R}$ " Candida strains characterized as shown in Table 1 were used. For a first study, differently designed peptides derived from bovine Catestatin (bCgA344-364) and human Catestatin (hCgA 352-372) (Table 2a) were tested against C. albicans ("S" and " $\mathrm{R}$ "). The MIC $(\mu \mathrm{g} / \mathrm{mL})$ is reported for each test (Table 2). Since, in vivo, $\mathrm{N}$ - and $\mathrm{C}$ - terminal modifications provide simple but useful approaches to improve peptide stability and effectiveness [32], we designed several peptides with shorter sequences than $\mathrm{b} / \mathrm{hC}$ ts including $\mathrm{N}$-terminal modification (Ac, acetylation, and $\mathrm{Pa}$, Palmatoylation) and C-terminal addition of tryptophane residue (W) (Table 2). Most amino acids (except Glycine), have 1 or 2 asymmetric atoms and can thus form enantiomers ( $L$ - and $D$-). The $D$-peptide can reduce susceptibility to proteolysis but also shows antimicrobial activity because the helical structure and amphiphilicity are unchanged. 
Table 1. Susceptibility of Candida strains tested. EUCAST (European Committee on Antimicrobial Susceptibility Testing) breakpoints were used for Amphotericin B, Fluconazole, Voriconazole, and CLSI (Clinical and Laboratory Standards Institute) breakpoints for Caspofungin. " $\mathrm{S}$ ", " $\mathrm{R}$ ", and "I" correspond to susceptible standard dosing regimen, resistant, therapeutic failure with increased exposure and susceptible increased exposure, respectively.

\begin{tabular}{|c|c|c|c|c|}
\hline Strain & Amphotericin B & Fluconazole & Voriconazole & Caspofungin \\
\hline & $\mathrm{MIC}(\mu \mathrm{g} / \mathrm{mL})$ & $\operatorname{MIC}(\mu \mathrm{g} / \mathrm{mL})$ & $\operatorname{MIC}(\mu \mathrm{g} / \mathrm{mL})$ & $\mathrm{MIC}(\mu \mathrm{g} / \mathrm{mL})$ \\
\hline C. albicans "S" & 0.19 "S" & 0.125 "S" & 0.002 "S" & 0.094 "S" \\
\hline C. albicans " $R$ " & 0.125 “S” & $>256$ “ $R$ " & $>32$ “ $\mathbf{R}^{\prime \prime}$ & 0.047 “S” \\
\hline C. tropicalis "S" & 0.125 "S" & 0.5 “S” & 0.047 "S" & 0.125 "S" \\
\hline C. tropicalis " $R^{\prime}$ & 0.125 "S" & 96 “ $\mathbf{R}^{\prime \prime}$ & 1.5 “ $\mathbf{R}$ " & 0.125 “S" \\
\hline C. glabrata "S" & 0.125 “S" & 3 "I" & 0.032 "S" & 0.25 “I” \\
\hline C. glabrata " $\mathrm{R}$ " & 0.5 “S" & $>256$ “ $R$ " & 8 “R” & 0.25 “I" \\
\hline C. lusitaniae "S" & 0.75 "S" & 0.38 "S" & 0.012 "S" & 0.125 "S" \\
\hline
\end{tabular}

Table 2. Antimicrobial activity against $C$. albicans of different bovine and human Cts-derived peptides. (a) Sequences and MIC $(\mu \mathrm{g} / \mathrm{mL})$ of the different peptides derived from bCts and bCtl against sensitive "S" and resistant " $R$ " C. albicans; (b) sequences and MIC of the different peptides derived from hCts and hCtl against sensitive " $\mathrm{S}$ " and resistant " $\mathrm{R}$ " C. albicans. L, levogyre and $D$, dextrogyre isomers. *Values obtained from Dartevelle et al. [28].

(a)

\begin{tabular}{|c|c|c|c|c|}
\hline & \multirow{2}{*}{ Peptide } & \multirow{2}{*}{ Sequence } & \multicolumn{2}{|c|}{ MIC $(\mu \mathrm{g} / \mathrm{mL})$ C. albicans } \\
\hline & & & “S" & “R" \\
\hline bCts & bCgA344-364 & $\begin{array}{c}\text { RSMRLSFRARGYGFRG } \\
\text { PGLQL }\end{array}$ & 30 & 50 \\
\hline bCtl & L-bCgA344-358 & R S M R L S F R A R G Y G F R & $7.9 *$ & 9.6 \\
\hline P1 & D-bCgA344-358 & R S M R L S F R A R G Y G F R & $5.5 *$ & 9.6 \\
\hline P2 & $L-b C g A 344-351$ & R S M R L S F R & 50 & 100 \\
\hline P3 & L-bCgA344-351 & Ac-R S M R L S F R & $>100$ & $>100$ \\
\hline $\mathbf{P 4}$ & $L-b C g A 344-351$ & 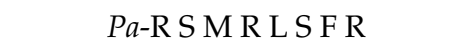 & $>100$ & $>100$ \\
\hline P5 & L-bCgA347-352 & R L S F R A-W & $>100$ & $>100$ \\
\hline P6 & $D-\mathrm{bCgA} 347-352$ & R L S F R A-W & $>100$ & $>100$ \\
\hline P7 & $L-b C g A 348-353$ & Ac-L S F R A R & $>100$ & $>100$ \\
\hline P8 & $L-b C g A 348-351$ & L S F R & $>100$ & $>100$ \\
\hline P9 & D-bCgA348-351 & L S F R & $>100$ & $>100$ \\
\hline P10 & L-bCgA348-351 & $A c-\mathrm{L} S \mathrm{~F} R$ & $>100$ & $>100$ \\
\hline P11 & L-bCgA348-351 & $P a-L S F R$ & $>100$ & $>100$ \\
\hline
\end{tabular}

(b)

\begin{tabular}{|c|c|c|c|c|}
\hline & \multirow{2}{*}{ Peptide } & \multirow{2}{*}{ Sequence } & \multicolumn{2}{|c|}{ MIC $(\mu \mathrm{g} / \mathrm{mL})$ C. albicans } \\
\hline & & & “S” & “R” \\
\hline hCts & hCgA352-372 & $\begin{array}{c}\text { S S M K LSFRARA Y G F R } \\
\text { PG PQL }\end{array}$ & $>240$ & $>240$ \\
\hline hCtl & $L-h C g A 352-366$ & S S M K LSFR A R A Y G F & 50 & 50 \\
\hline P12 & $L-\mathrm{hCgA352-366}$ & Ac-S S M K L S F R A R G Y G F R & $>100$ & $>100$ \\
\hline P13 & $L-\mathrm{hCgA352-366}$ & $P a-S$ S M K L S F R A R G Y G F R & $>100$ & $>100$ \\
\hline P14 & $L-h C g A 352-359$ & SSMKLSFR & $>100$ & $>100$ \\
\hline P15 & L-hCgA352-359 & $A c-S$ S M K L S F R & $>100$ & $>100$ \\
\hline P16 & $L-h C g A 352-359$ & $P a-S$ S M K L S F R & $>100$ & $>100$ \\
\hline P17 & $L-h C g A 355-360$ & $A c-\mathrm{K}$ L S F R A & $>100$ & $>100$ \\
\hline P18 & $L-h C g A 354-359$ & M K L S F R & $>100$ & $>100$ \\
\hline P19 & L-hCgA354-359 & 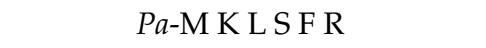 & $>100$ & $>100$ \\
\hline
\end{tabular}

Among the bovine sequences (Table 2), the most active peptide corresponds to the $D$-form of bCtl with a MIC of $5.5 \mu \mathrm{g} / \mathrm{mL}$ and $9.6 \mu \mathrm{g} / \mathrm{mL}$ against the " $\mathrm{S}$ " and " $\mathrm{R}$ " forms 
of $C$. albicans, respectively, whereas among the $L-\mathrm{hCtl}$ the most active peptide is the complete $L$-hCtl sequence with a MIC of $50 \mu \mathrm{g} / \mathrm{mL}$ for the "S" and " $R$ " forms of $C$. albicans. These data demonstrate the important role of the Arginine (R) residue at the N-terminal position in the bCtl sequence and of the $D$-structure as previously demonstrated for other microorganisms [27-29].

\subsection{Antimicrobial Activity of $L-$ and $D-b C t l$ against $C$. tropicalis and C. glabrata}

The antimicrobial activity of $L$ - and $D$-Ctl are similar against $C$. albicans and $C$. tropicalis (" $\mathrm{S}$ " and " $\mathrm{R}$ ") and the present data confirm the highest activity of $D$-bCtl against $C$. glabrata (" $\mathrm{S}$ " and " $\mathrm{R}$ "). It is also important to highlight the low MIC $(2 \mu \mathrm{g} / \mathrm{mL})$ obtained for $L$ - and $D$-Ctl against $C$. tropicalis " $\mathrm{R}$ " (Table 3 ).

Table 3. Antifungal activity of $L-\mathrm{bCts}, L-\mathrm{hCts}, L-\mathrm{bCtl}$, and $D-\mathrm{bCtl}$ against various strains of Candida. The percentage of growth inhibition of the indicated yeasts in the presence of different concentrations of $L$-bCts, $L$-hCts, $L-b C t \mathrm{l}$, and $D$-bCtl was determined by broth microdilution assays. Each MIC, defined as the lowest concentration of a drug able to inhibit $100 \%$ of fungal growth, was determined using a modified Gompertz model. Experiments were performed in triplicate. "S": sensitive, "R": resistant. * Values obtained from Dartevelle et al. [28].

\begin{tabular}{|c|c|c|c|c|c|c|}
\hline $\begin{array}{l}\text { Candida } \\
\text { Strain. }\end{array}$ & $\begin{array}{c}\text { Candida } \\
\text { albicans } \\
\text { "S" }\end{array}$ & $\begin{array}{c}\text { Candida } \\
\text { albicans } \\
\text { "R" }\end{array}$ & $\begin{array}{c}\text { Candida } \\
\text { tropicalis } \\
\text { "S" }\end{array}$ & $\begin{array}{c}\text { Candida } \\
\text { tropicalis } \\
\text { " } \mathbf{R}^{\prime}\end{array}$ & $\begin{array}{c}\text { Candida } \\
\text { glabrata } \\
\text { "S" }\end{array}$ & $\begin{array}{c}\text { Candida } \\
\text { glabrata } \\
\text { "R" }\end{array}$ \\
\hline $\begin{array}{l}\text { MIC of } L-b C t s \\
\quad(\mu \mathrm{g} / \mathrm{mL})\end{array}$ & 30 & 50 & 50 & 20 & $>100$ & $>100$ \\
\hline $\begin{array}{l}\text { MIC of } L-h C t s \\
\quad(\mu \mathrm{g} / \mathrm{mL})\end{array}$ & $>240$ & $>240$ & $>240$ & $>240$ & $>240$ & $>240$ \\
\hline $\begin{array}{c}\text { MIC of } L-b C t l \\
\quad(\mu \mathrm{g} / \mathrm{mL})\end{array}$ & $7.9 *$ & 9.6 & 9.8 & 2.0 & 38.2 & 61.4 \\
\hline $\begin{array}{c}\text { MIC of } D \text {-bCtl } \\
\quad(\mu \mathrm{g} / \mathrm{mL})\end{array}$ & $5.5^{*}$ & 9.6 & 8.1 & 2.0 & 13.4 & 15.0 \\
\hline
\end{tabular}

\subsection{TEM Analysis of $L$ - and $D$ - $b C t$ against " $S$ " and " $R$ " C. albicans}

The interaction of the peptides with $C$. albicans was examined by TEM in order to investigate the mechanism used by $L$ - and $D$-Ctl to inhibit the $C$. albicans growth. This technique shows the permeabilization of the fungal membrane and the variable efficiency of $L$-bCtl and $D$-bCtl towards " $\mathrm{S}$ " and " $\mathrm{R}$ " C. albicans (Figures 1 and 2). TEM images clearly demonstrate fungal membrane lysis and secretion of intracellular material induced by both peptides (Figures 1 and 2). These images show a higher proportion of cell lysis of the sensitive strain of $C$. albicans when the concentrations of $L$-Ctl or D-Ctl increase (Figure 1), whereas the proportion of cell lysis appears lower for " $R$ " $C$. albicans (Figure 2).

\subsection{Antimicrobial Activity of $L-b C t l$ Combined with Albumin against C. albicans}

BSA was not active at the molecular concentrations tested. Since the MIC ratio (L-bCts)/MIC (L-bCtl) is close to 4 (Table 2), $1 \mu \mathrm{M} \mathrm{L}$-bCtl and $4 \mu \mathrm{M} \mathrm{L}$-bCts were combined with BSA $(1.5,6,30 \mathrm{nM})$ and $(6,24,120 \mathrm{nM})$ respectively and tested against C. albicans. BSA was unable to improve the antimicrobial activity of $1 \mu \mathrm{M} L-b C t l$ with a growth inhibition ratio evaluated at $30 \%$. In contrast, with $4 \mu \mathrm{M} \mathrm{L}$-bCts and the same BSA/peptide, ratio, more than $90 \%$ of inhibition was achieved with $24 \mathrm{nM}$ BSA (Figure 3). These data show that the combination $L$-bCts and BSA have a synergistic effect against $C$. albicans as well as that the C-terminal sequence of $L$-bCts (GPGLQL) is important for the interaction with BSA. The synergistic effect between BSA and $L-b C t l$ is obtained especially when BSA concentrations are low ( 6 and $24 \mathrm{nM}$ ), in contrast to high BSA concentrations of $120 \mathrm{nM}$ where the antimicrobial activity against Candida was not improved (see discussion part). 


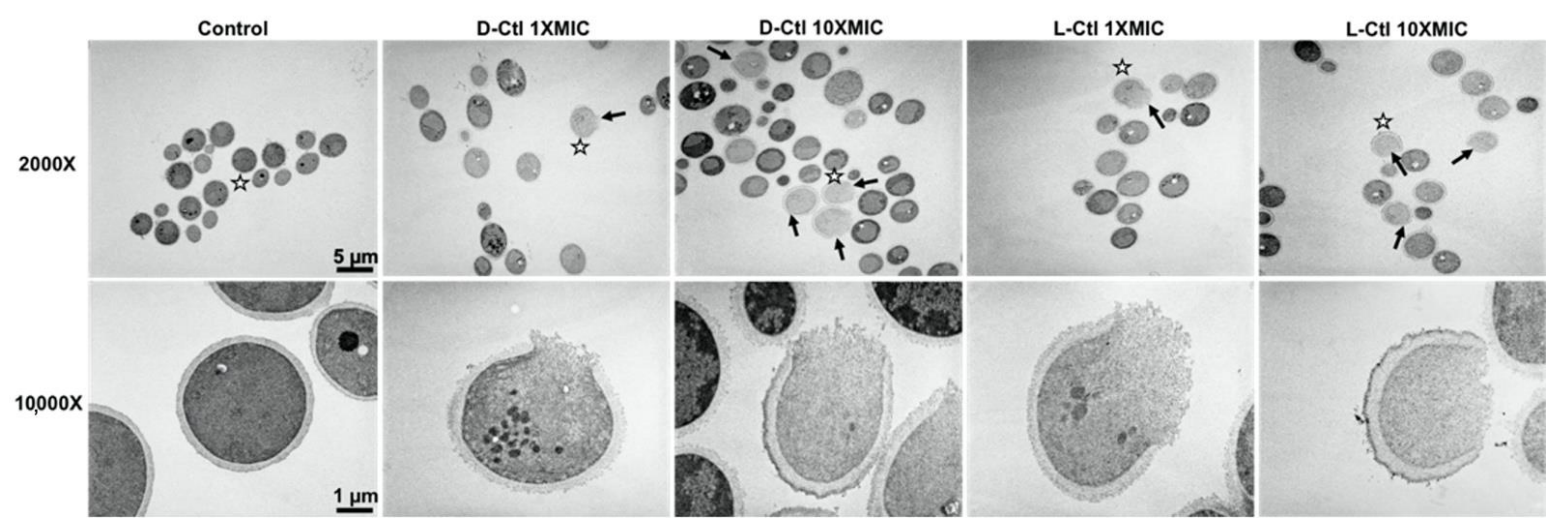

Figure 1. Transmission electron microscopy images of cells from " $\mathrm{S}$ " C. albicans, treated with $D$-bCtl or $L$-bCtl at different concentrations, compared to untreated cells. $D$-bCtl or $L$-bCtl were used at concentrations of $1 \times \mathrm{MIC}$ and $10 \times \mathrm{MIC}$ and incubated for $1 \mathrm{~h}$ at $37^{\circ} \mathrm{C}$ with minimal shaking. White stars indicate which cell is magnified at $10,000 \times$. Black arrows localize lysed cells.

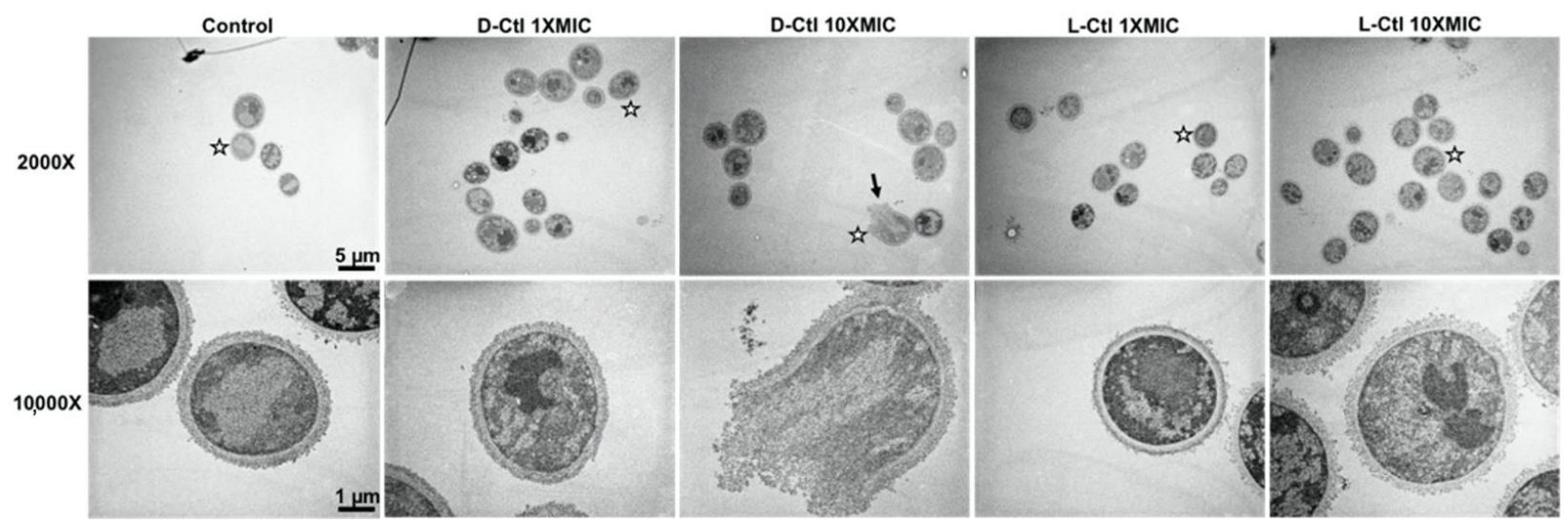

Figure 2. Transmission electron microscopy images of cells from a resistant strain of Candida albicans, treated with $D$-Ctl or $L-C t l$ at different concentrations, compared to untreated cells. $D$-Ctl or $L-C t l$ were used at concentrations of $1 \times \mathrm{MIC}$ and $10 \times \mathrm{MIC}$ and incubated for $1 \mathrm{~h}$ at $37^{\circ} \mathrm{C}$ with minimal shaking. White stars indicate which cell is magnified at $10,000 \times$. Black arrows localize lysed cells.

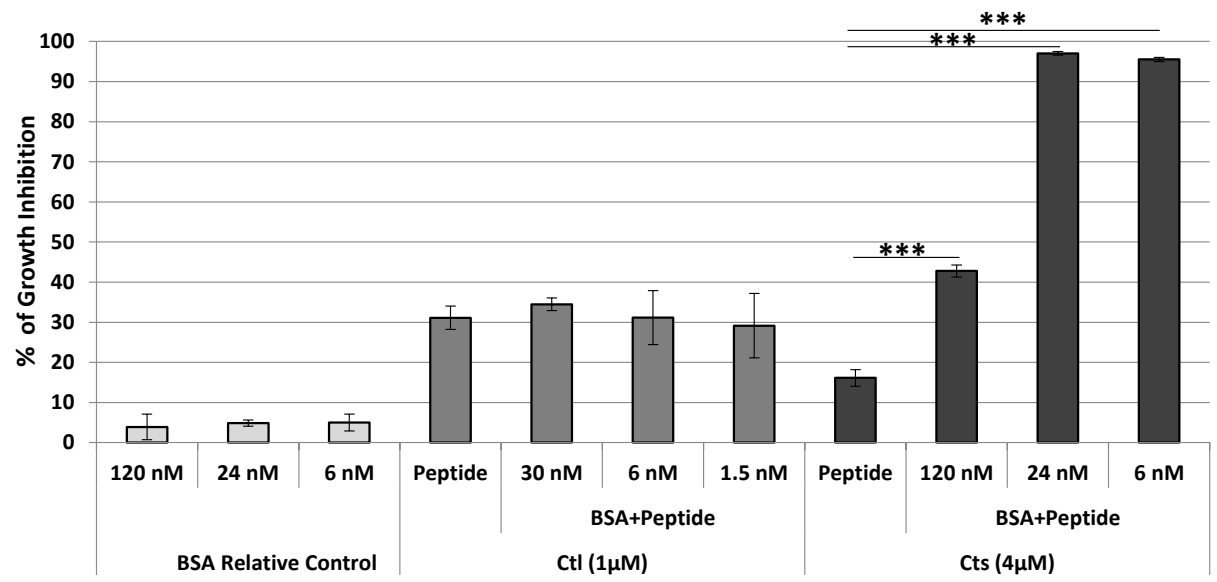

Figure 3. Antimicrobial activity of $L-b C t l$ and $L$-bCts with BSA against $C$. albicans. BSA was used with a molar concentration of 30,6 , and $1.5 \mathrm{nM}$ for $\mathrm{Ctl}(1 \mu \mathrm{M})$ or 120,24 and $6 \mathrm{nM}$ for $L$-bCts $(4 \mu \mathrm{M})$. The growth inhibition of BSA (controls) is reported only for the concentrations used with $L$-bCts where we obtained synergistic antimicrobial effects. No antimicrobial effects were obtained for BSA combined with $L$-bCtl., ${ }^{* * *} p \leq 0.001$ with 1 way ANOVA comparing peptide only to BSA plus peptide treatments. 
We have also demonstrated the non-toxicity of the combination L-bCts with BSA (Figure 4).

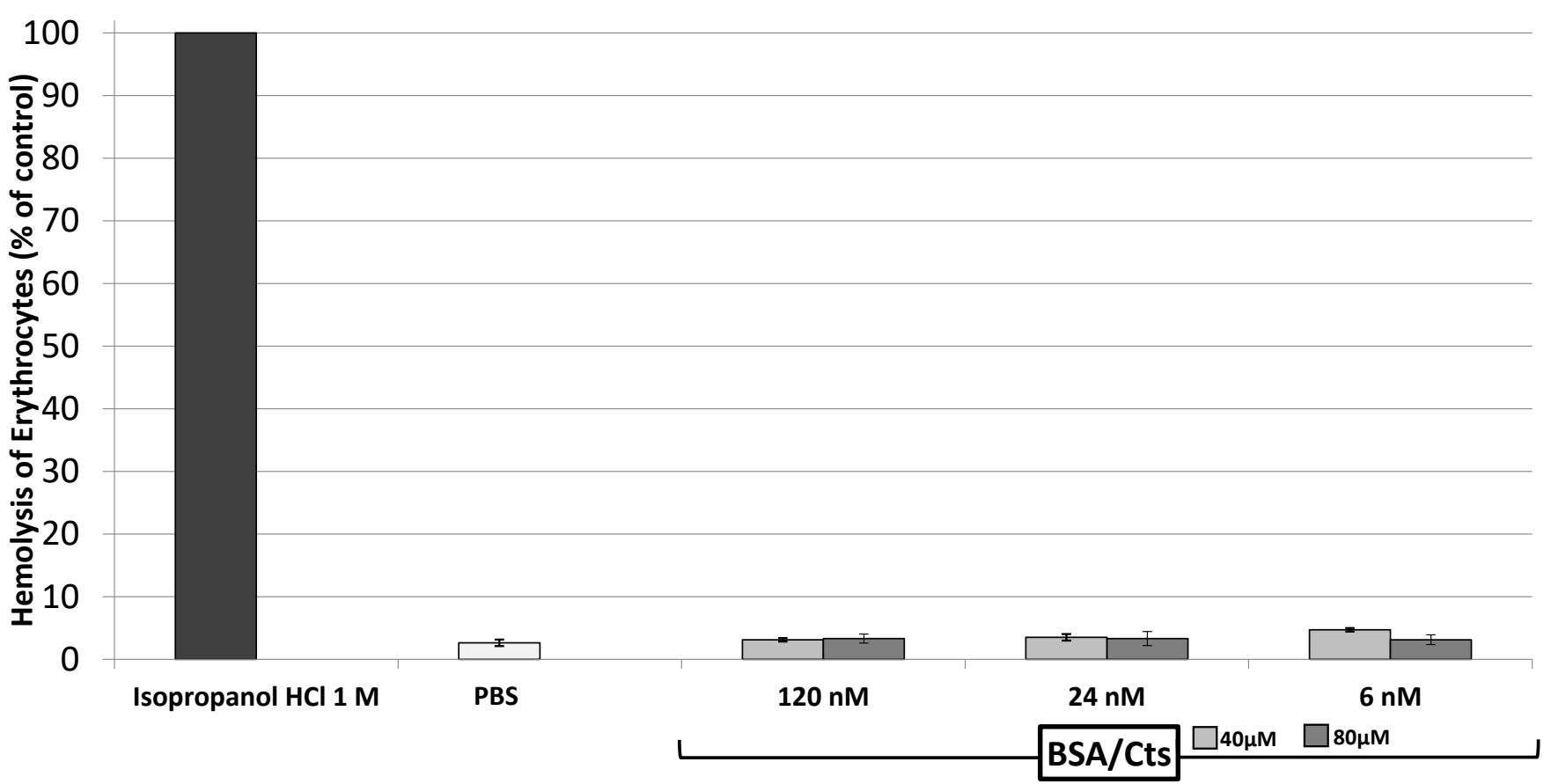

Figure 4. Non-toxicity of BSA/L-bCts complex. Hemolytic assays of erythrocytes with BSA (120, 24, and $6 \mathrm{nM}$ ) plus $L$-bCts $(40$ and $80 \mu \mathrm{M})$. All the treatments were statistically significant compared to the positive control of the hemolytic test with One way ANOVA.

\subsection{Biophysical Study of the Interaction Cts-Albumin}

In order to understand the synergistic effect of albumin on $L$-bCts activity, we investigated a possible interaction between $L-b C t s / L-b C t l$ and BSA using QCM.

BSA was first deposited on the top of the quartz crystal and a change in the third frequency resonance was measured, corresponding to the variation of $\frac{\Delta f_{v}}{v}=7 \mathrm{~Hz}$ (with $v=3$ ). The next deposition was performed with $\mathrm{Cts}$ with a frequency variation of $\frac{\Delta f_{v}}{v}=22$ $\mathrm{Hz}$ (Figure 5). According to Sauerbrey's approximation, the deposited mass was calculated following the relation:

$$
m=-C \frac{\Delta f}{v}
$$

where $C$ is a constant characteristic of the crystal plate $\left(C \approx 17.7 \mathrm{ng} \cdot \mathrm{cm}^{-2} \cdot \mathrm{Hz}^{-1}\right.$ for the quartz plates used here).

In our case, the deposited masses of BSA and $L-b C$ ts were 88.5 and $566.4 \mathrm{ng} \cdot \mathrm{cm}^{-2}$ respectively, corresponding to a massic ratio $L$-bCts/BSA of 6.4 or a molar ratio of 177 . These data indicate the presence of significant interactions between $L-b C$ ts and BSA.

On the opposite, under the same experimental conditions, a second deposition with $L-b C t l$ instead of $L$-bCts was performed but the results indicate almost no frequency variation, corresponding to an absence of interaction between BSA and L-bCtl (Figure 5).

QCM analysis indicates that $L$-bCts interacts with BSA but not $L$-bCtl (Figure 5), suggesting the importance of the C-terminal end of L-bCts (GPGLQL) (see Table 2). These data confirm the antimicrobial activities previously obtained for BSA- $L-b C t s / L-b C t$ combinations (Figure 3). 

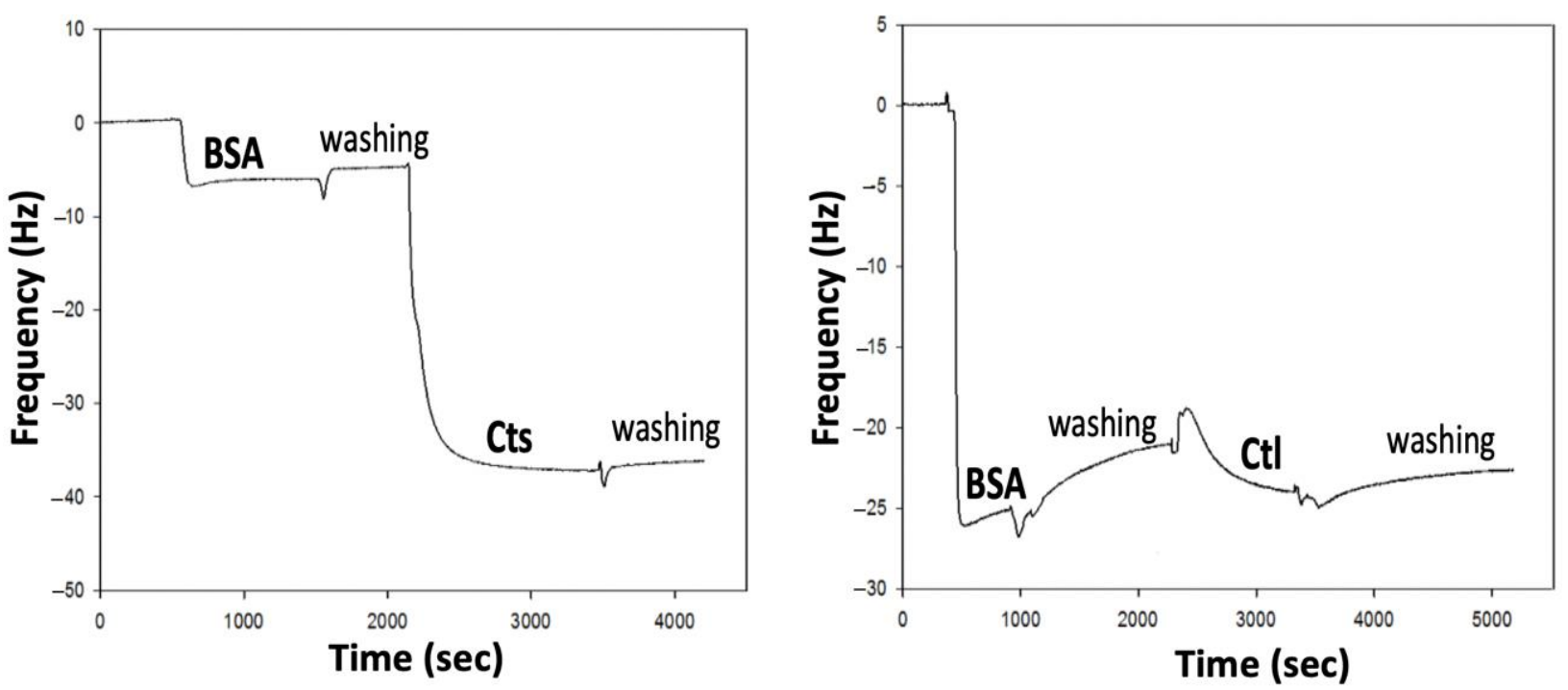

Figure 5. Quartz Crystal Microbalance (QCM) analysis of the interaction BSA with L-bCts or L-bCtl. The analysis was performed at $37^{\circ} \mathrm{C}$ in PBS pH 7.2 with a first injection of $2 \mathrm{mg} / \mathrm{mL}$ BSA $(400 \mu \mathrm{L}$, and a second injection of $1 \mathrm{mg} / \mathrm{mL} \mathrm{L-bCts} \mathrm{or} L$-bCtl $(400 \mu \mathrm{L})$.

\section{Discussion}

Previous epidemiological studies have confirmed that fungal infections will certainly be a growing concern in the years to come, as resistance of $C$. albicans as well as non-albicans Candida strains to existing antifungal drugs is becoming more and more prevalent [8-10]. In this context, the development of new antifungal drugs remains a major challenge to overcome the prevalence of drug-resistant fungal pathogens. Over the last few years, an increasing interest in the development of new antifungal therapeutic agents based on the pharmaceutical exploitation of HDPs is spreading $[12,25,26]$. The present study showed that $L$ - and $D-\mathrm{bCtl}$, as well as the combination of $L-\mathrm{bCts}$ with BSA exhibit an antimicrobial activity against Candida strains. With regard to $C$. albicans " $\mathrm{S}$ " $L$-bCtl, $D$-bCtl and $L-b C t s$ combined with $24 \mathrm{nM}$ BSA are active with a MIC of $7.9 \mu \mathrm{M}, 5.5 \mu \mathrm{M}$ and $4 \mu \mathrm{M}$, respectively.

Our previous paper [28] demonstrated the interesting activity of $\mathrm{P} 1,(D-\mathrm{bCtl})$ against C. albicans. The others P2-P11 peptides were designed to evaluate the activity of shorter fragments and to define the structural domain for the activity. These peptides were designed taking into account the role of the N-terminal sequences (344-351; RSMRLSFR) and (348-358; LSFRARGYGFR) for the antimicrobial activities [17]. The role of the LSFR tetrapeptide was emphasized by our previous study showing that it participates in the inhibition of microbial enzymes [33]. Of great interest, the $\mathrm{N}$ - and C-terminal modifications (Ac, Pa, and $\mathrm{W}$ ) added in P3-P7, P10-P11 sequences are unable to improve the anti-Candida activities and the helical domain (S6 to Y12) of $L$ - and D-bCtl is important for the anti-Candida activity [34].

Our results based on antifungal assays demonstrated that $D-\mathrm{bCtl}$ is a potent antifungal agent against sensitive and resistant strains of C. albicans, C. tropicalis, and C. glabrata (Tables 2 and 3), whereas the efficiency of $L$-bCtl significantly decreases against $C$. glabrata strains, as the MIC values obtained in the presence of the resistant strain o C. glabrata strain increased to $61.4 \mu \mathrm{g} / \mathrm{mL}$ for $L-b C t l$ and remained stable for $D-b C t l$, with a value of $15.0 \mu \mathrm{g} / \mathrm{mL}$.

The present study demonstrated the improved efficiency of $D$-bCtl compared to $L-b C t l$ against a wide range of Candida strains. This could be due to the high stability of bCtl [24] and more particularly the $D$-isomer $[27,28]$.

Images obtained by transmission electron microscopy (TEM) demonstrated the permeabilization of the fungal membrane and the leakage of the intracellular material induced by the $L-b C t l$ and $D$-bCtl peptides after a short incubation time $(1 \mathrm{~h})$ in the presence of the pathogen (Figures 2 and 3). We have previously reported that electrostatic interac- 
tions between the arginine residues of the positively charged $L$-bCtl peptide sequence and the negatively charged membrane lipids are responsible for the formation of pores of $1 \mathrm{~nm}$ diameter across the membrane [27,28]. Indeed, the thicker and stiffer membrane domains that result from these interactions generate membrane defects that allow peptide passage across membranes and ultimately lead to membrane breakage. A previous study demonstrated the role of ergosterol in facilitating the penetration of a CgA-derived peptide into membranes [35]. Furthermore, at the intracellular level, we showed that $L$-bCts are able to interact with Calmodulin to inhibit intracellular calmodulin-binding enzymes such as Calcineurin [21]. In this context, the bCts-derived peptides represent innovative and potent HDPs.

No less important is the role that albumin may play in enhancing the activities of $L$-bCts. This finding is different from that reported for others HDPs [36,37]. Our hypothesis is that the Cts-BSA combination may protect the peptide from proteolytic degradation and improve its biodisponibility, as reported for several peptides [38,39]. In addition, these data have been supported by our clinical study in collaboration with the Intensive Care Unit of Strasbourg showing that infusion with a low concentration of albumin improves the recovery of patients with nosocomial infections. Compared to $20 \%$ albumin infusion, we showed that continuous $4 \%$ albumin is effective in reducing care-related infections in shock patients by increasing the availability of antimicrobial peptides. Due to its anti-oxidative properties, albumin prevents peptide oxidation. In the bCtl sequence, several residues $(\mathrm{M}, \mathrm{F}$, and $\mathrm{Y})$ may be oxidized and induce structural modifications. The combination with albumin may prevent the oxidation of these residues.

Finally, preventive antifungal protection of the oral mucosa is a long-term research prospect. This preventive approach could be based on surface modifications of medical devices such as removable dental prothesis, which are partly responsible for the emergence of oral candidosis. As such, the use of a surface coating functionalized with $D$-bCtl might help reduce infections associated with medical devices. Nevertheless, research for the development of preventive or therapeutic means of action against oral candidosis should be continued. This study will be extended by the analysis of the interaction of bCtl on the other Candida strains. In vivo studies will be performed with infected animal models in order to compare the effects of bCtl ( $L$ or $D$ - forms) and the combination BSA and $L$ or $D$-bCts.

\section{Materials and Methods}

\subsection{Preparation and Characterization of Synthetic Cts and Its Derived-Peptides}

Chemically synthesized peptides derived from bovine-Catestatin (bCts) and humanCatestatin (hCts) were supplied by Pepmic (Suzhou, China). The purity of these peptides was tested by reverse phase (RP) HPLC with a Dionex HPLC system (Ultimate 3000; 13 Sunnyvale, CA, USA) on a Vydac 208 TP C 8 column $(2.1 \times 150 \mathrm{~mm})$ equipped with a Vydac 208 TP 14 pre-column $(7.5 \times 2.1 \mathrm{~mm})$ (Vydac, AIT France, Houilles, France) according to the previously described method [24].

\subsection{Antimicrobial Assays against the Different Strains of Candida}

Strains of Candida albicans, Candida tropicalis and Candida glabrata, frequently found in cases of oral candidosis, were tested for $L-b C t l$ and $D$-bCtl antimicrobial activity. The sensitive strain of C. albicans (ATCC $10231^{\mathrm{TM}}$ ) was provided by ATCC (Manassas, VA, USA). The resistant strain of $C$. albicans, the sensitive and resistant strains of $C$. tropicalis as well as the sensitive and resistant strains of $C$. glabrata were kindly provided by Dr Valérie Letscher-Bru (Laboratory of Parasitolology and Medical Mycology, Strasbourg, France). The susceptibility of each strain is reported in Table 1.

Each Candida strain was first plated on agar plates and cultured for $24 \mathrm{~h}$ at $37^{\circ} \mathrm{C}$. After incubation, one colony per isolate was transferred into $5 \mathrm{~mL}$ of Sabouraud medium $\mathrm{pH} 5.6$ (Sigma-Aldrich, Le Pont-de-Claix, France) supplemented with tetracycline $(10 \mu \mathrm{g} / \mathrm{mL})$ and cefotaxime $(10 \mu \mathrm{g} / \mathrm{mL})$ and incubated aerobically under agitation at $37^{\circ} \mathrm{C}$ for $24 \mathrm{~h}$. 
The resulting cultures were resuspended at an absorbance of $0.001\left(\mathrm{OD}_{600 \mathrm{~nm}}=0.001\right)$ in Sabouraud medium. The $\mathrm{OD}_{600 \mathrm{~nm}}$ was evaluated with a spectrophotometer (BIO-RAD Smatspec $^{\mathrm{TM}}$ plus, Schiltigheim, France). In preliminary experiments, we tested RPMI-1640 culture and Sabouraud media. Similar data were obtained but the experiments were more reproducible with Sabouraud than with RPMI1640. Therefore, Sabouraud medium was used in the present study.

The yeasts $\left(\mathrm{OD}_{600 \mathrm{~nm}}=0.001\right)$ were then plated on 96-well microplates and treated with different concentrations of the peptides of interest. After $24 \mathrm{~h}$ incubation at $37{ }^{\circ} \mathrm{C}$ under agitation, yeast growth was assessed by optical density $\left(\mathrm{OD}_{600 \mathrm{~nm}}\right)$ using a microplate spectrophotometer (Multiscan EX, Thermo Fisher Scientific, Waltham, MA, USA). All tests were performed in triplicate. The MIC (minimal inhibitory concentration), defined as the lowest concentration of drug able to inhibit $100 \%$ of the growth of a pathogen, was determined for the different peptides against all previously described Candida strains, using a modified Gompertz model [40].

The same method was used to evaluate the MICs of peptide/bovine serum albumin combinations (BSA).

\subsection{Cells Viability}

Erythrocytes cells viability was assessed according to the previously reported method [17]. Cell viability was reported as the percentage of cell survival compared to positive controls. Each assay was tested in triplicate and data were compared to the positive control $\left({ }^{* * *} p \leq 0.001\right)$ with One way ANOVA.

\subsection{Samples Preparation for Transmission Electron Microscopy}

Precultures of sensitive and resistant Candida albicans strains were incubated for $2 \mathrm{~h}$ at $37{ }^{\circ} \mathrm{C}$ without shaking on glass bottom 24-well microplates previously treated with poly-L-lysine. The $L-b C t$ or $D$-bCtl peptides at concentrations of $1 X$ MIC and 10X MIC were then added to the culture and incubated for $1 \mathrm{~h}$ at $37{ }^{\circ} \mathrm{C}$ with minimal shaking. The control samples correspond to the incubation of the different Candida albicans strains without any prior treatment. After $1 \mathrm{~h}$ incubation with or without each peptide of interest and a brief rinsing in $0.125 \mathrm{M}$ cacodylate buffer, cells were fixed for $2 \mathrm{~h} 30 \mathrm{~min}$ in a $4 \%(v / v)$ glutaraldehyde buffered in $0.1 \mathrm{M}$ sodium phosphate at $\mathrm{pH}$ 7.2. This step was followed with three $10 \mathrm{~min}$ washes in $0.1 \mathrm{M}$ phosphate buffer at $\mathrm{pH}$ 7.2. Then the samples were post-fixed in a freshly prepared $2 \%(v / v)$ aqueous solution of potassium permanganate for $45 \mathrm{~min}$ at room temperature. The samples were washed three more times and dehydrated in graded series of ethanol of $7 \mathrm{~min}$ each. The composition of Spurr resin (Sigma Aldrich, Saint Quentin Fallavier, France) used was as follows: NSA (Nonenyl Succinic anhydride; 5.9 g), ERL4221 (cycloaliphatic epoxy-resin; $4.10 \mathrm{~g}$ ), DER736 (Diglycidyl ether of polypropyleneglycol; $1.58 \mathrm{~g}$ ), and DMAE (Dimethylaminoethanol; $0.1 \mathrm{~g}$ ) as an accelerator. The samples were transferred successively in 1 vol Spurr resin/ 2 vol absolute ethanol for $15 \mathrm{~min}$, then in $1 \mathrm{vol}$ Spurr resin/1 vol absolute ethanol for $30 \mathrm{~min}$ and 2 times $1 \mathrm{~h}$ in 100\% Spurr resin. Finally, after a new change overnight in $100 \%$ epoxy resin, the samples were successively placed in fresh resin at room temperature, $37^{\circ} \mathrm{C}, 45^{\circ} \mathrm{C}$ for $24 \mathrm{~h}$ and let $48 \mathrm{~h}$ in a $65{ }^{\circ} \mathrm{C}$ oven for polymerization.

\subsection{Transmission Electron Microscopy}

Ultrathin sections were performed using a Reichert Jung Ultra-cut E ultra-microtome (Leica Microsystems, Nanterre, France) equipped with a diamond knife. Ultrathin sections were collected on 100 mesh Formvar coated grids and stained with 5\% uranyl acetate solution (Euromedex, Souffelweyersheim, France). After rinsing, the grids were stained with a $4 \%$ lead citrate solution for $10 \mathrm{~min}$ (Euromedex, Souffelweyersheim, France). Samples were observed with a Philips EM 208 instrument (FEI Company, Eindhoven, Netherlands) operating with an accelerating voltage of 70 KV. Images were recorded on Kodak SO163 film (Sigma Aldrich, Saint-Quentin Fallavier, France). After development, negatives were 
scanned at 600 dpi with EPSON/PERFECTION V750 PRO (Epson France, Lavallois Perret, France).

\subsection{Quartz Crystal Microbalance Analysis}

The construction of the multilayer film was monitored in situ with a quartz crystal microbalance (QCM) (Q-Sense E4, Goteborg, Sweden). A quartz crystal coated with a silica layer $\left(\mathrm{SiO}_{2}\right)$ was used. After crystal cleaning with a $2 \%(v / v)$ Hellmanex solution (Hellma Analytics, Müllheim, Germany) for half an hour, combining with a rinsing step with milliQ water, $400 \mu \mathrm{L}$ of PBS solution ( $\mathrm{pH}$ 7.4) was injected into the measurement cell. After baseline stabilization, $400 \mu \mathrm{L}$ of bovine serum albumin (BSA) in PBS $(2 \mathrm{mg} / \mathrm{mL}$ at $37^{\circ} \mathrm{C}$ ) was deposited as the first layer and the deposition step was performed for $3 \mathrm{~min}$. The stability of the first layer was assessed by performing a wash step for $5 \mathrm{~min}$ with PBS solution. The ability of bCts and bCtl ( $L$-isomers) to interact with BSA was performed with a 3-min deposition step of $400 \mu \mathrm{L}$ for each peptide at a concentration of $1 \mathrm{mg} / \mathrm{mL}$, followed by a 5 -min rinse step with PBS. The quartz crystal was excited at its fundamental frequency (about $5 \mathrm{MHz}$ ), as well as at the third, fifth, seventh, and ninth overtones (denoted by $v=3$, 5,7 , and 9 and corresponding to $15,25,35$, and $45 \mathrm{MHz}$, respectively). Changes in the resonance frequencies $(-\Delta \mathrm{f} v)$ were measured at these four frequencies. An increase in the normalized frequency $-\Delta \mathrm{f} v / v$ is often associated with a proportional increase in the mass coupled to the quartz crystal. The mass and molecular ratio of BSA/L-bCts or BSA/L-bCtl ( $L$-isomers) were calculated according to Sauerbrey approximation [41].

\subsection{Statistical Analysis}

The proportions of lysed cells of each group tested were compared to the control experiment using the two-sided Fisher exact test and one-way analysis of variance test (ANOVA) with statistical significance set at $\alpha=0.05$.

\subsection{Data Availability} P10645.

Sequence of Catestatin and Cateslytin: Uni protKB,CMGA_Bovin P05059;CMGA_Human

\section{Conclusions}

Within the limitations of this original study, we can conclude that in vitro $D$-bCtl and the combination of BSA with $L$-bCts are potential candidates for the development of new antifungal drugs for the treatment of oral candidosis due to Candida and non-Candida albicans, without no detrimental side effects.

Author Contributions: Conceptualization. M.-H.M.-B., A.M. and Y.H.; methodology. A.M. and E.M.; validation. N.K., F.S.-Y., Y.H. and D.M.; formal analysis. N.K.; investigation. S.H. and E.M.; resources. N.K., F.S. and D.M.; data curation. E.M. and S.H.; writing-original draft preparation. M.-H.M.-B. and D.M.; writing-review and editing. D.M. and N.K.; visualization. F.S.-Y.; supervision. Y.H., P.L. and M.-H.M.-B.; project administration. Y.H. and M.-H.M.-B.; funding acquisition. P.L., M.-H.M.-B. and Y.H. All authors have read and agreed to the published version of the manuscript.

Funding: This research was supported by Inserm and the University of Strasbourg (SATT Conectus). Francesco Scavello was supported by the University 'Italo-Francese' in the context of 'Vinci Project 2014 ( $\mathrm{n}^{\circ}$ C2-72) attributed to the Department of Biology, Ecology and Earth Science University of Calabria, Arcavacata di Rende, Italy and the INSERM_UMR 1121, Biomaterials and BioEngeneering, Strasbourg, France.

Institutional Review Board Statement: Not applicable.

Informed Consent Statement: Not applicable.

Data Availability Statement: Not applicable.

Acknowledgments: We thank Valérie Bru-Letscher (Laboratory of Parasitology and Medical Mycology, University of Strasbourg, France) for providing strains of Candida, the Pierre Fabre Dermo- 
Cosmetique Institute (Research and Development Department) Toulouse, France for the preparation of the Cts-derived peptides and Drs. Pauline Dartevelle, Christian Boehler (Faculty of Odontology of Strasbourg and Inserm UMR 1121) for preliminary experiments.

Conflicts of Interest: The authors declare no conflict of interest.

\section{References}

1. Thompson, D.S.; Carlisle, P.L.; Kadosh, D. Coevolution of morphology and virulence in Candida species. Eukaryot. Cell 2011, 10, 1173-1182. [CrossRef] [PubMed]

2. Muadcheingka, T.; Tantivitayakul, P. Distribution of Candida albicans and non-albicans Candida species in oral candidiasis patients: Correlation between cell surface hydrophobicity and biofilm forming activities. Arch. Oral Biol. 2015, 60, 894-901. [CrossRef] [PubMed]

3. Hu, L.; He, C.; Zhao, C.; Chen, X.; Hua, H.; Yan, Z. Characterization of oral candidiasis and the Candida species profile in patients with oral mucosal diseases. Microb. Pathog. 2019, 134, 103575. [CrossRef]

4. Siopi, M.; Tarpatzi, A.; Kalogeropoulou, E.; Damianidou, S.; Vasilakopoulou, A.; Vourli, S.; Pournaras, S.; Meletiadis, J. Epidemiological Trends of Fungemia in Greece with a Focus on Candidemia during the Recent Financial Crisis: A 10-Year Survey in a Tertiary Care Academic Hospital and Review of Literature. Antimicrob. Agents Chemother. 2020, 64, e01516-19. [CrossRef]

5. Zakhem, A.E.; Istambouli, R.; Alkozah, M.; Gharamti, A.; Tfaily, M.A.; Jabbour, J.F.; Araj, G.F.; Tamim, H.; Kanj, S.S. Predominance of Candida Glabrata among Non-albicans Candida Species in a 16-Year Study of Candidemia at a Tertiary Care Center in Lebanon. Pathogens 2021, 10, 82. [CrossRef]

6. Kmeid, J.; Jabbour, J.F.; Kanj, S.S. Epidemiology and burden of invasive fungal infections in the countries of the Arab League. J. Infect. Public Health 2020, 13, 2080-2086. [CrossRef]

7. Giacobbe, D.R.; Maraolo, A.E.; Simeon, V.; Magnè, F.; Pace, M.C.; Gentile, I.; Chiodini, P.; Viscoli, C.; Sanguinetti, M.; Mikulska, M.; et al. Changes in the relative prevalence of candidaemia due to non-albicans Candida species in adult in-patients: A systematic review, meta-analysis and meta-regression. Mycoses 2020, 63, 334-342. [CrossRef]

8. Puig-Asensio, M.; Padilla, B.; Garnacho-Montero, J.; Zaragoza, O.; Aguado, J.M.; Zaragoza, R.; Montejo, M.; Muñoz, P.; RuizCamps, I.; Cuenca-Estrella, M.; et al. Epidemiology and predictive factors for early and late mortality in Candida bloodstream infections: A population-based surveillance in Spain. Clin. Microbiol. Infect. 2014, 20, O245-O254. [CrossRef]

9. Chapman, B.; Slavin, M.; Marriott, D.; Halliday, C.; Kidd, S.; Arthur, I.; Bak, N.; Heath, C.H.; Kennedy, K.; Morrissey, C.O.; et al. Changing epidemiology of candidaemia in Australia. J. Antimicrob. Chemother. 2017, 72, 1103-1108. [CrossRef]

10. Arendrup, M.C.; Dzajic, E.; Jensen, R.H.; Johansen, H.K.; Kjaeldgaard, P.; Knudsen, J.D.; Kristensen, L.; Leitz, C.; Lemming, L.; Nielsen, L.; et al. Epidemiological changes with potential implication for antifungal prescription recommendations for fungaemia: Data from a nationwide fungaemia surveillance programme. Clin. Microbiol. Infect. 2013, 19, E343-E353. [CrossRef]

11. WHO. Available online: https://www.who.int/antimicrobial-resistance/interagency-coordination-group/final-report/en/ (accessed on 25 April 2019).

12. Afacan, N.J.; Yeung, A.T.; Pena, O.M.; Hancock, R.E. Therapeutic potential of host defense peptides in antibiotic-resistant infections. Curr. Pharm. Des. 2012, 18, 807-819. [CrossRef] [PubMed]

13. Phan, T.K.; Bevins, C.L.; Hulett, M.D. Editorial: Advances in the Immunology of Host Defense Peptide: Mechanisms and Applications of Antimicrobial Functions and Beyond. Front. Immunol. 2021, 12, 637641. [CrossRef] [PubMed]

14. Metz-Boutigue, M.-H.; Goumon, Y.; Strub, J.M.; Lugardon, K.; Aunis, D. Antimicrobial chromogranins and proenkephalin-Aderived peptides: Antibacterial and antifungal activities of chromogranins and proenkephalin-A-derived peptides. Ann. N. Y. Acad. Sci. 2003, 992, 168-178. [CrossRef] [PubMed]

15. Shooshtarizadeh, P.; Zhang, D.; Chich, J.F.; Gasnier, C.; Schneider, F.; Haikel, Y.; Aunis, D.; Metz-Boutigue, M.-H. The antimicrobial peptides derived from chromogranin/secretogranin family, new actors of innate immunity. Regul. Pept. 2010, 165, 102-110. [CrossRef]

16. Aslam, R.; Atindehou, M.; Lavaux, T.; Haïkel, Y.; Schneider, F.; Metz-Boutigue, M.-H. Chromogranin A-derived peptides are involved in innate immunity. Curr. Med. Chem. 2012, 19, 4115-4123. [CrossRef]

17. Briolat, J.; Wu, S.D.; Mahata, S.K.; Gonthier, B.; Bagnard, D.; Chasserot-Golaz, S.; Helle, K.B.; Aunis, D.; Metz-Boutigue, M.-H. New antimicrobial activity for the catecholamine release-inhibitory peptide from chromogranin A. Cell. Mol. Life Sci. 2005, 62, 377-385. [CrossRef]

18. Zhang, T.; Jiang, H.; Wang, T.; Liu, S.; Rausch-Fan, X.; Yang, P. Salivary chromogranin A and myeloid-related protein-8/14 from periondontitis patients with type 2 diabetes. Quintessence Int. 2019, 50, 808-814.

19. Mahata, S.K.; O-Connor, D.T.; Mahata, M.; Yoo, S.H.; Taupenot, L.; Wu, H.; Gill, B.M.; Parmer, R.J. Novel autocrine feedback control of catecholamine release. A discrete chromogranin a fragment is a noncompetitive nicotinic cholinergic antagonist. J. Clin. Investig. 1997, 100, 1623-1633. [CrossRef]

20. Rocca, C.; De Bartolo, A.; Grande, F.; Rizzuti, B.; Pasqua, T.; Giordano, F.; Granieri, M.C.; Occhiuzzi, M.A.; Garofalo, A.; Amodio, N.; et al. Cateslytin abrogates lipopolysaccharide-induced cardiomyocyte injury by reducing inflammation and oxidative stress through toll like receptor 4 interaction. Int. Immunopharmacol. 2021, 94, 107487. [CrossRef] 
21. Zhang, D.; Shooshtarizadeh, P.; Laventie, B.J.; Colin, D.A.; Chich, J.F.; Vidic, J.; de Barry, J.; Chasserot-Golaz, S.; Delalande, F.; Van Dorsselaer, A.; et al. Two chromogranin a-derived peptides induce calcium entry in human neutrophils by calmodulin-regulated calcium independent phospholipase A2. PLOS ONE 2009, 4, e4501. [CrossRef]

22. Eissa, N.; Hussein, H.; Mesgna, R.; Bonin, S.; Hendy, G.N.; Metz-Boutigue, M.-H.; Bernstein, C.N.; Ghia, J.E. Catestatin Regulates Epithelial Cell Dynamics to Improve Intestinal Inflammation. Vaccines 2018, 6, 67. [CrossRef] [PubMed]

23. Muntjewerff, E.M.; Dunkel, G.; Nicolasen, M.J.T.; Mahata, S.K.; van den Bogaart, G. Catestatin as a target for treatment of inflammatory diseases. Front. Immunol. 2018, 9, 2199-2208. [CrossRef]

24. Aslam, R.; Marban, C.; Corazzol, C.; Jehl, F.; Delalande, F.; Van Dorsselaer, A.; Prévost, G.; Haïkel, Y.; Taddei, C.; Schneider, F.; et al. Cateslytin, a chromogranin A derived peptide is active against Staphylococcus aureus and resistant to degradation by its proteases. PLoS ONE 2013, 8, e68993. [CrossRef] [PubMed]

25. Cado, G.; Aslam, R.; Séon, L.; Garnier, T.; Fabre, R.; Parat, A.; Chassepot, A.; Voegel, J.-C.; Senger, B.; Schneider, F.; et al Self-Defensive Biomaterial Coating against Bacteria and Yeasts: Polysaccharide Multilayer Film with Embedded Antimicrobial Peptide. Funct. Mater. 2013, 23, 4801-4809. [CrossRef]

26. Mateescu, M.; Baixe, S.; Garnier, T.; Jierry, L.; Ball, V.; Haikel, Y.; Metz-Boutigue, M.-H.; Nardin, M.; Schaaf, P.; Etienne, O.; et al. Antibacterial Peptide-Based Gel for Prevention of Medical Implanted-Device Infection. PLoS ONE 2015, 10, e0145143. [CrossRef] [PubMed]

27. Zaet, A.; Dartevelle, P.; Daouad, F.; Ehlinger, C.; Quilès, F.; Francius, G.; Boehler, C.; Bergthold, C.; Frisch, B.; Prévost, G.; et al. D-Cateslytin, a new antimicrobial peptide with therapeutic potential. Sci. Rep. 2017, 7, 15199. [CrossRef] [PubMed]

28. Dartevelle, P.; Ehlinger, C.; Zaet, A.; Boehler, C.; Rabineau, M.; Westermann, B.; Strub, J.M.; Cianferani, S.; Haïkel, Y.; MetzBoutigue, M.-H.; et al. D-Cateslytin: A new antifungal agent for the treatment of oral Candida albicans associated infections. Sci. Rep. 2018, 8, 9235. [CrossRef]

29. Scavello, F.; Mutschler, A.; Hellé, S.; Schneider, F.; Chasserot-Golaz, S.; Strub, J.M.; Cianferani, S.; Haikel, Y.; Metz-Boutigue, M.-H. Catestatin in innate immunity and Cateslytin-derived peptides against superbugs. Sci. Rep. 2021, 11, 15615. [CrossRef]

30. Austermeier, S.; Pekmezovic, M.; Porschitz, P.; Lee, S.; Kichik, N.; Moyes, D.L.; Ho, J.; Ketowicz, N.K.; Naglik, J.R.; Hube, B.; et al Albumin neutralizes hydrophobic toxins and modulates Candida albicans Pathogenecity. mBio 2021, 12, e0053121. [CrossRef]

31. Schneider, F.; Dureau, A.F.; Hellé, S.; Betscha, C.; Senger, B.; Cremel, G.; Boulmedais, F.; Strub, J.M.; Corti, A.; Meyer, N.; et al. A Pilot Study on Continuous Infusion of $4 \%$ Albumin in Critically Ill Patients: Impact on Nosocomial Infection via a Reduction Mechanism for Oxidized Substrates. Crit. Care Explor. 2019, 1, e0044. [CrossRef]

32. Han, Y.; Zhang, M.; Lai, R.; Zhang, Z. Chemical modifications to increase the therapeutic potential of antimicrobial peptides. Peptides 2021, 146, 170666. [CrossRef] [PubMed]

33. Akaddar, A.; Doderer-Lang, C.; Marzahn, M.R.; Delalande, F.; Mousli, M.; Helle, K.; Van Dorsselaer, A.; Aunis, D.; Dunn, B.M.; Metz-Boutigue, M.H.; et al. Catestatin, an endogenous chromogranin A-derived peptide, inhibits in vitro growth of Plasmodium falciparum. Cell. Mol. Life Sci. 2010, 67, 1005-1015. [CrossRef] [PubMed]

34. Sugawara, M.; Resende, J.M.; Moraes, C.M.; Marquette, A.; Chich, J.F.; Metz-Boutigue, M.H.; Bechinger, B. Membrane structure and interactions of human catestatin by multidimensional solution and solid-state NMR spectroscopy. FASEB J. 2010, 24, 1737-1746. [CrossRef]

35. Maget-Dana, R.; Metz-Boutigue, M.H.; Helle, K.B. The N_terminal domain of chromogranin A interacts with monolayers of membrane lipids of fungal and mammalian compositions. Ann. N. Y. Acad. Sci. 2002, 971, 352-354. [CrossRef]

36. Sivertsen, A.; Isaksson, J.; Leiros, H.K.; Svenson, J.; Svendsen, J.S.; Brandsdal, B.O. Synthetic cationic antimicrobial peptides bind with their hydrophobic parts to drug site II of human serum albumin. BMC Struct. Biol. 2014, 14, 4-17. [CrossRef]

37. Svenson, J.; Brandsdal, B.O.; Stensen, W.; Svendsen, J.S. Albumin binding of short cationic antimicrobial micropeptides and its influence on the in vitro bactericidal effect. J. Med. Chem. 2007, 50, 3334-3339. [CrossRef]

38. Gallo, M.; Vanni, D.; Esposito, S.; Alaimo, N.; Orvieto, F.; Rulli, F.; Missineo, A.; Caretti, F.; Bonelli, F.; Veneziano, M.; et al Oligomerization, albumin binding and catabolism of therapeutic peptides in the subcutaneous compartment: An investigation on lipidated GLP-1 analogs. J. Pharm. Biomed. Anal. 2022, 210, 114566. [CrossRef] [PubMed]

39. Tian, R.; Zhu, S.; Zeng, Q.; Lang, L.; Ma, Y.; Kiesewetter, D.O.; Liu, Y.; Fu, X.; Lau, J.; Zhu, G.; et al. An Albumin Sandwich Enhances in Vivo Circulation and Stability of Metabolically Labile Peptides. Bioconjug. Chem. 2019, 30, 1711-1723. [CrossRef] [PubMed]

40. Lambert, R.J.; Pearson, J. Susceptibility testing: Accurate and reproducible minimum inhibitory concentration (MIC) and noninhibitory concentration (NIC) values. J. Appl. Microbiol. 2000, 88, 784-790. [CrossRef] [PubMed]

41. Sauerbrey, G. Use of quartz crystal vibrator for weighting thin films on a microbalance. Z. Physik. 1959, 155, 206-222. [CrossRef] 